\title{
Of Non-Horses, Quantum Mechanics, and the Establishment Clause
}

\author{
John M. Bickers* \\ To use a horse to show that a horse is not a horse is not as good as \\ using a non-horse to show that a horse is not a horse. ${ }^{1}$
}

\section{INTRODUCTION}

The pronouncements of Chuang Tzu are seldom easy; his remark about non-horses is certainly no exception. The best explanations suggest that he was responding to a group of philosophers who argued that attributes are so connected to their objects that to speak of the object without the attribute was a form of nonsense. ${ }^{2}$ True, Chuang Tzu seems to tell us, but it is almost equally nonsensical to fail to recognize the singularity of objects: for surely if a white horse is not a horse then a non-horse is not either.

As is often the case with the writings of Chuang Tzu, he makes one notice several truths in getting where he wishes to go. He does no more than state a logical truth when announcing that a non-horse is not a horse. Yet he leaves us with a mystery: what, precisely, is a non-horse? $\mathrm{He}$ may have had in mind a shoe, a tea kettle, a tree, or a mountain. Indeed, he may have meant them all and many other things as well. It is impossible to identify any particular object with a term like non-horse. Indeed, it is difficult to imagine a single criterion by which one of them takes pride of place. It is difficult to imagine a coherent way to

\footnotetext{
* Assistant Professor, Salmon P. Chase College of Law, Northern Kentucky University. I am indebted to Professor Matthew Zacate of the NKU Physics Department for listening patiently to my early ideas regarding quantum mechanics and correcting them gently. My thanks go out to the faculty of the Washburn College of Law and my own colleagues at Chase, who heard early versions of this paper and offered considerable suggestions for improvement. My thanks go also to the faculty of the Washington University School of Law, who allowed me to present a more mature version as part of their on-going series of workshops for junior faculty. Any remaining errors are, sadly, my own.

1. The COMPlete Works of ChUANG TZU 40 (Burton Watson trans., 1968).

2. Most prominently, Kung-sun Lung, whose Discourse on the White Horse makes the claim: "A white horse is not a horse ... . The word 'horse' denotes a shape, 'white' denotes a color. What denotes color does not denote shape.” 1 Fung YU-LAN, A History OF ChINESE PhiLOSOPHY, 20304 (Derk Bodde trans., Princeton Univ. Press 1983) (1952).
} 
determine whether a tool shed is more of a non-horse than a mountain. If size is the criterion, the mountain differs more from a horse than a shed. If, on the other hand, the test is natural versus manufactured, it is the tool shed that differs the most.

One thing, at least, is certain: nothing can be both a horse and a nonhorse. From this tautology arises an interesting corollary: nothing can be neither. All things must either be horses or not. It is incoherent to speak of something that is neither horse nor non-horse. Nor is it helpful to attempt to imagine something that is half way between a horse and a non-horse. Once an object has left the category of horses, logically it must be a non-horse. ${ }^{3}$ A centaur is not neutral between horses and nonhorses. It is a non-horse just as surely as a tea kettle is.

Yet for much of the past half-century, the legal community in the United States, in its quest to understand the Establishment Clause of the First Amendment, has hunted for a mystical animal that is neither horse nor non-horse. Forests of paper and lakes of ink have perished in the quest for a test that will isolate those government actions that are neutral "between religion and nonreligion." 4

This Article will argue that the efforts have failed because the quest was impossible. Part II will examine briefly some of the ways that courts and commentators have endeavored to achieve neutrality under the Establishment Clause. Using the insights of Chuang Tzu and the contradictory results of a pair of recent cases ${ }^{5}$ dealing with displays of the Ten Commandments, ${ }^{6}$ this part will suggest that, at least in areas of

3. See Judicial Humour-Construction of a Statute, 8 CRIM. L.Q. 137 (1966) (an amusing reading of a law which makes ponies into small birds).

4. The phrase first appeared in a Supreme Court opinion in the concurrence by Justice Goldberg in School District v. Schempp, 374 U.S. 203, 305 (1963) (Goldberg, J., concurring). Justice Goldberg cited to no particular authority for the concept. It first appeared in a majority opinion five years later. Epperson v. Arkansas, 393 U.S. 97, 104 (1968) (stating "The First Amendment mandates governmental neutrality between religion and religion, and between religion and nonreligion"). Subsequent attempts to find its earliest source have tended to focus on the 1947 decision in Everson v. Board of Education, 330 U.S. 1 (1947). See, e.g., McCreary County v. ACLU of Ky., 545 U.S. 844, 860 (2005). Intriguingly, the language used in Everson was different, perhaps significantly so. In allowing a New Jersey township to reimburse parents who paid for public transportation to take their children to parochial schools, the Court pronounced that the establishment clause "requires the state to be a neutral in its relations with groups of religious believers and non-believers." Everson, 330 U.S. at 18.

5. Van Orden v. Perry, 545 U.S. 677 (2005); McCreary County, 545 U.S. 844.

6. The Ten Commandments have been a particularly intense area for divisiveness and litigation. This may well represent an erroneous view of American legal history. See, e.g., Steven K. Green, The Fount of Everything Just and Right? The Ten Commandments as a Source of American Law, 14 J.L. \& RELIGION 525, 558 (1999-2000) (surveying the historical landscape and concluding that "absent a handful of early cases, judicial reliance on the Ten Commandments as a source of law was all but nonexistent"). 
government religious speech, there simply is no logical escape from the conundrum of neutrality.

Part III will seek an escape through a non-logical path: quantum mechanics. As will be seen, quantum mechanics offers more than simply a new way to calculate values at the sub-atomic level. Quantum mechanics illustrates a whole series of new phenomena, which are utterly inexplicable when viewed through the lens of classical physics. Indeed, some of the philosophical puzzles were so stark that the solution derived by a group of scholars working in Denmark - and forever after known as the Copenhagen School-was to reject the very nature of reality assumed by the classicists. ${ }^{7}$ The Copenhagen approach required understanding of a concept so non-intuitive that it might well have been a teaching of Chuang Tzu. There was no reality, they said, independent of the measurement of reality. ${ }^{8}$

Part IV will apply this Copenhagen solution to the Establishment Clause dilemma discussed in Part II. ${ }^{9}$ One current Justice, this Article will argue, may have hinted at just such a solution. The Article will then examine the results of some of the cases that have come out of the lower courts since the two Supreme Court cases of 2005, and determine whether the adoption of a Copenhagen solution would solve our Chuang Tzu problem. I will be so bold as to suggest that using this approach would do far more to establish religious peace than any of the other current options. ${ }^{10}$

\section{NeUtRALITY AND THE NON-HORSE}

\section{A. The Court's Quixotic Quest}

It is now customary to refer to Everson v. Board of Education as the source of the idea that the Establishment Clause requires neutrality between religion and nonreligion. ${ }^{11}$ Omitted by this casual assertion is

7. V.K. Thankappan, QuANTUM MeChanics 448 (2d ed. 1993).

8. See infra Part III.B.

9. I am unaware of quantum mechanics serving precisely this purpose before; however, it is certainly not unknown for providing guidance to legal problems more generally. See generally Laurence H. Tribe, Essay, The Curvature of Constitutional Space: What Lawyers Can Learn from Modern Physics, 103 HARV. L. REV. 1 (1989).

10. I do this with a fear that in this area, too, Chuang Tzu offers wise counsel: "[y]our advice is like the praying mantis that waved its arms angrily in front of an approaching carriage-it just isn't up to the job." Watson, supra note 1, at 133.

11. See, e.g., McCreary County v. ACLU of Ky., 545 U.S. 844, 874 (2005) ("The importance of neutrality as an interpretive guide is no less true now than it was when the Court broached the principle in Everson v. Board of Ed. of Ewing."). 
the intriguing set of circumstances that faced the Court in that case. The dilemma was over a reimbursement plan for use by students riding public buses to school, a plan that included payment to those students who did so not to reach public schools, but Catholic schools. ${ }^{12}$ One can view such a plan in two alternate, mutually exclusive ways. The approach adopted by the majority was to see the plan as the provision of a government benefit to citizens, religious and nonreligious alike, not significantly different from "ordinary police and fire protection, connections for sewage disposal, public highways and sidewalks." ${ }^{\prime 3}$ Of course, noted the Court, religious institutions benefit from such services, but withdrawal of them only from religious organizations would "require the state to be their adversary." 14

The other possible characterization of the plan appeared in the dissent authored by Justice Rutledge. ${ }^{15}$ From the perspective of the taxpayer, public funds were supporting religious education, which Justice Rutledge identified with the practice of government-enforced tithing that "had been the life blood of establishment before and after other compulsions disappeared."16 Viewed from this perspective, a prohibition on extending to students at private religious schools a benefit conveyed to those attending public schools would not make the state "unneutral." 17

Although much of the fight over the meaning of the Establishment Clause since Everson has been a historical one, ${ }^{18}$ there seems nothing particularly illogical about the positions of Justices Black and Rutledge. It is true that the withdrawal of a benefit only from religious people and practices is not "neutral between religion and nonreligion." 19 It is equally true that the provision of benefits to religious schools is not

12. Everson v. Bd. of Educ., 330 U.S. 1, 3 (1947).

13. Id. at $17-18$.

14. See id. at 18

15. Justice Jackson's dissent makes similar arguments, but Justice Rutledge most directly engages the Court's characterization of its decision as neutral. See id. at 28 (Rutledge, J., dissenting).

16. Id. at 41

17. Id. at 59

18. Unfortunately, the nature of the historical evidence is such that the same facts are sometimes used to support both sides of the discussion. See, e.g., id. at 11-12 (majority opinion) (approving of the New Jersey transportation support while citing to Madison's "great Memorial and Remonstrance" against Virginia's proposed tax to support religion); id. at 37 (Rutledge, J., dissenting) (disapproving of the New Jersey transportation support for parochial schools while citing to Madison's "historic Memorial and Remonstrance" against Virginia's proposed tax to support religion).

19. Everson is not the only case to embrace this approach. See, e.g., Bd. of Educ. v. Allen, 392 U.S. 236, 238 (1968) (permitting state purchase of textbooks for loan to parochial schools); Comm. for Pub. Educ. \& Religious Liberty v. Regan, 444 U.S. 646 (1980) (permitting state funding of testing at parochial schools). 
neutral. ${ }^{20}$ The Court in 1947 did not avail itself of the opportunity to confront the problem caused by the requirement of neutrality, but the opportunity would continue to reappear throughout the next sixty years.

Rich and full tellings of the tale and the importance of Lemon $v$. Kurtzman $^{21}$ exist. $^{22}$ For the purposes of this Article, it is worth remembering that Chief Justice Burger sought in that case to construct an analytical framework from disparate threads of previous jurisprudence. ${ }^{23}$ The Grand Unified Theory ${ }^{24}$ the Court developed ${ }^{25}$ encouraged us to consider the intent of the government actor, the effect upon the public, and the entanglement between the government and the religion. ${ }^{26}$ At first glance, the theory seems both effective and complete. Conceptually, it seems to cover all the areas that might cause concern about religious liberty. ${ }^{27}$

Yet, as with the Grand Unified Theories of physics, Lemon has proven less valuable in practice. Just as previously attempted Grand

20. Indeed, the dissenters in cases allowing such benefits typically make this point. See, e.g., Allen, 392 U.S. at 251 (Black, J., dissenting) ("To authorize a State to tax its residents for such church purposes is to put the State squarely in the religious activities of certain religious groups that happen to be strong enough politically to write their own religious preferences and prejudices into the laws."); Regan, 444 U.S. at 671 (Stevens, J., dissenting) (stating that the Court's authorization of state support for testing programs "confirms my view ... that the entire enterprise of trying to justify various types of subsidies to nonpublic schools should be abandoned").

21. 403 U.S. 602 (1971). The case considered, and found unconstitutional, salary supplements, textbook support, and other financial assistance from Rhode Island and Pennsylvania to religious schools. Id. at 606-07.

22. See, e.g., Leonard W. Levy, The Establishment Clause: Religion and the First AMENDMENT 155-59 (2d ed., The Univ. of N.C. Press 1994) (1986).

23. Lemon, 403 U.S. at 612 ("Every analysis in this area must begin with consideration of the cumulative criteria developed by the Court over many years. Three such tests may be gleaned from our cases.").

24. In physics, this term is used to describe an explanation that unifies electromagnetism, the weak nuclear force, and the strong nuclear force. STEPHEN W. HAWKING, A BRIEF HiSTORY OF TIME 74 (1988).

25. Of course, Justice O'Connor famously denied that the Lemon test was such a theory. See Bd. of Educ. v. Grumet, 512 U.S. 687, 718 (1994) ("It is always appealing to look for a single test, a Grand Unified Theory that would resolve all the cases that may arise under a particular Clause. There is, after all, only one Establishment Clause, one Free Speech Clause, one Fourth Amendment, one Equal Protection Clause."). The Court has nevertheless used Lemon—when it uses it—as just such an organizing principle.

26. See Lemon, 403 U.S. at 612-13 ("First, the statute must have a secular legislative purpose; second, its principal or primary effect must be one that neither advances nor inhibits religion; finally, the statute must not foster "an excessive government entanglement with religion." (citations omitted)).

27. Indeed, confidence in the Lemon test remains profound in many quarters. Many federal courts continue to rely on Lemon. See, e.g., Vasquez v. Los Angeles County, 487 F.3d 1246, 1254 (9th Cir. 2007) ("[Lemon] continues to set forth the applicable constitutional standard for assessing the validity of governmental actions challenged under the Establishment Clause.”). 
Unified Theories had to ignore phenomena they could not explain, ${ }^{28}$ the Supreme Court has similarly found cases in which Lemon was less than useful. In such cases, the Court occasionally simply refuses to acknowledge it. ${ }^{29}$ Of course, there are Justices who openly loathe Lemon and consistently call for its explicit rejection. ${ }^{30}$ Perhaps more puzzling to the observer are those Justices who remain content to use Lemon as the appropriate test in some cases but utterly ignore it in others. ${ }^{31}$ Perhaps this inconsistent application best explains the appearance in the last quarter-century of other analytical models to replace, augment, or explain Lemon. It is not insignificant, though, that many of the models proceed from the same starting point as Lemon itself: the desire for a decision-making methodology that will ensure that the government action is neutral between religion and nonreligion.

These other tests have taken a variety of forms. Some Justices proposed that the relevant test was one of coercion, ${ }^{32}$ and the idea that the government cannot force any one to worship or support churches has a great deal of intuitive appeal. ${ }^{33}$ Despite strong uses in important cases,

28. Most importantly, gravity. See HAwKING, supra note 24, at 74 ("[T] are not all that grand, nor are they fully unified, as they do not include gravity.").

29. Famously, the Court allowed Nebraska's practice of opening legislative sessions with a prayer by a paid chaplain. Marsh v. Chambers, 463 U.S. 783, 794-95 (1983). The Court's only mention of Lemon in doing so was the almost casual observation that the Eighth Circuit opinion had used the Lemon test and found that the practice violated all three parts of the test. Id. at 786 . Although the Court reversed the court below, the opinion makes no further mention of the Lemon test.

30. Perhaps never more memorably than by one of its most implacable opponents: "Like some ghoul in a late-night horror movie that repeatedly sits up in its grave and shuffles abroad, after being repeatedly killed and buried, Lemon stalks our Establishment Clause jurisprudence once again, frightening the little children and school attorneys of Center Moriches Union Free School District." Lamb's Chapel v. Center Moriches Union Free Sch. Dist., 508 U.S. 384, 398 (1993) (Scalia, J., concurring).

31. None more prominently than Chief Justice Burger, who authored both the Lemon test and the opinion for the Court in Marsh v. Chambers, which ignored it. See Marsh, 463 U.S. at 786.

32. The idea of coercion as the key prohibition of the Establishment Clause may have arisen in the school prayer and Bible-reading cases, see, e.g., Engel v. Vitale, 370 U.S. 421 (1962), Sch. Dist. v. Schempp, 374 U.S. 203 (1963), but it reached its clearest articulation in a series of dissents and concurrences to opinions that overtly used the Lemon test. See, e.g., Bd. of Educ. v. Mergens, 496 U.S. 226, 260 (1990) (Kennedy, J., concurring in part and in the judgment) ("[T]he government cannot coerce any student to participate in a religious activity."); County of Allegheny v. ACLU Greater Pittsburgh Chapter, 492 U.S. 573, 659 (1989) (Kennedy, J., concurring in part and dissenting in part) ("[G]overnment may not coerce anyone to support or participate in any religion or its exercise.").

33. There had been a tradition in many colonies, of course, of established churches which received mandatory church support. See, e.g., LeVY, supra note 22, 2-26. On the other hand, four colonies-Delaware, New Jersey, Pennsylvania, and Rhode Island - had never established a church at all. $I d$. at 27-28. Even in the colonies with taxpayer-funded established churches, there had long been an undercurrent that coerced religion was worthless to God as well as an offense against liberty. Perhaps the most famous exposition of this belief was in James Madison's Memorial and 
a disagreement between the proponents of the test may have prevented it from developing any permanent hold over the Establishment Clause. ${ }^{34}$

The next test to enter the arena had perhaps the strangest history of all. So linked with a particular Justice that it is frequently labeled "Justice O'Connor's endorsement test," 35 this test focused on whether the government action made one's religion relevant to political standing within the community. ${ }^{36}$ This "clarification of our Establishment Clause doctrine" ${ }^{37}$ would prohibit government speech conveying to minorities that they were disfavored members of the community, and convey to members of the majority faith that they were specially favored and valued by the government. ${ }^{38}$ The test required, though, that courts evaluate the government speech at issue in context. ${ }^{39}$

Unlike the coercion test, which may not seek neutrality, the endorsement test found its very reason for being in the pursuit of that goal. Justice O'Connor noted that government practices could not

Remonstrance against Religious Assessments, which opposed a tax to be used to support churches within the Commonwealth of Virginia. Madison argued that "what is here a right towards men, is a duty towards the Creator. It is the duty of every man to render to the Creator such homage and such only as he believes to be acceptable to him." 8 JAMES MADISON, A Memorial and Remonstrance, in THE PAPERS OF JAMES MADISON 298, 299 (Robert A. Rutland et al. eds., 1973).

34. Arguably, the triumphant moment for the test came in a government speech case that also marked a split between two of its chief advocates. See Lee v. Weisman, 505 U.S. 577 (1992). In considering the appearance of a Rabbi to give a nondenominational blessing at a middle school graduation, Justice Kennedy wrote for the Court that social pressure could be coercive. Id. at 581 . Justice Scalia, in a bitter dissent, insisted that only the criminal or taxing power of the state was coercive. Id. at 632 (Scalia, J., dissenting). Intriguingly, neither of these warring opinions expressly sought neutrality. In his concurrence, however, Justice Souter did. Although he noted that neutrality was not "self-revealing," id. at 627 (Souter, J., concurring), it is noteworthy that for Justice Souter neutrality was still the goal to be sought, and the application of the coercion test not inconsistent with it. $I d$. at 609.

35. An October 12, 2008 Westlaw search of the Journals and Law Reviews database for the phrase "Justice O'Connor's endorsement" (including those who refer to it as "analysis" as well as "test") returned 405 distinct articles.

36. See Lynch v. Donnelly, 465 U.S. 668, 692 (1984) (O’Connor, J., concurring) (At issue was a display, in a park in Pawtucket, of Christmas cutout figures that included both secular items and some which depicted the birth of Jesus.).

37. Id. at 687 .

38. Id. at 688

39. Id. at 679. Many commentators concluded that the Court had created a "plastic reindeer rule," see, e.g., George M. Janocsko, Beyond the "Plastic Reindeer Rule": The Curious Case of County of Allegheny v. American Civil Liberties Union, 28 DUQ. L. REV. 445 (1990), a "three reindeer rule," see, e.g., Bradley S. Tupi, Religious Freedom and the First Amendment, 45 DUQ. L. REV. 195, 236 (2007), or even a "three-plastic animals rule," see, e.g., Michael W. McConnell, Religious Freedom at a Crossroads, 59 U. CHI. L. REV. 115, 127 (1992). I confess that I have always been more fascinated by Pawtucket's inclusion of a clown, a dancing elephant, and a robot as symbols of Christmas. See Donnelly v. Lynch, 525 F. Supp. 1150, 1155 (D.R.I. 1981) (listing contents of the Christmas display), rev'd 465 U.S. 668 (1984). 
endorse the faiths of some citizens "[i]f government is to be neutral in matters of religion." 40

\section{B. Other Views of Neutrality}

Neutrality appealed to the Everson Court, and appeals to many today, because it seems inherently just. When our pluralistic society contains fierce and unrelenting partisans on opposite sides of an issue, the role of the judiciary as a neutral arbiter or umpire ${ }^{41}$ between them seems appropriate. Of course, genuine attempts to remain neutral may seem unfair to losing participants. ${ }^{42}$ Putting aside conspiratorial theories of both sides, however, observers are left with the unmistakable fact that Establishment Clause cases, especially at the Supreme Court, seem to have listed to one side or another despite protestations (often by both the majority and dissent in the same case) that they were seeking the neutral solution. The logical challenge faced by the Everson Court has not receded, and the various attempts to resolve it only highlight the difficulty of the quest.

It was inevitable that scholars would enter the fray in endeavoring to explain the role of neutrality as alternate tests contended for advocates among the members of the Supreme Court. After all, Everson may have given birth to the ideal of Establishment Clause neutrality, but it was a law professor who best articulated it as a thing worth seeking. Professor Kurland's epic, Of Church and State and the Supreme Court, ${ }^{43}$ remains vital today, but his optimism about the nature of the disagreements in the Supreme Court ${ }^{44}$ does not still seem justifiable. ${ }^{45}$

More recently, some scholars have argued that neutrality was not a guide to the Court during much of the formative period of Establishment

40. County of Allegheny v. ACLU Greater Pittsburgh Chapter, 492 U.S. 573, 627 (1989).

41. "Judges are like umpires. Umpires don't make the rules, they apply them." Confirmation Hearing on the Nomination of John G. Roberts, Jr. To Be Chief Justice of the United States: Hearing Before the S. Comm. on the Judiciary, 109th Cong. 55 (2005) (statement of John G. Roberts, Jr.).

42. Indeed, in the related area of private speech on public land, one scholar has observed that a policy of neutrality is unfair, as it inherently favors majority religions. See Alberto B. Lopez, Equal Access and the Public Forum: Pinette's Imbalance of Free Speech and Establishment, 55 BAYLOR L. REV. 167, 222 (2003).

43. See Philip B. Kurland, Of Church and State and the Supreme Court, 29 U. CHI. L. REV. 1 (1961) (arguing that together the religion clauses prohibited the government from using religion as the basis for government action, regardless of whether the action would benefit or burden religion).

44. "There is little quarrel, today, about the goals to be achieved by the religion clauses of the first amendment. The problem that has bemused and confused the Court has been that of stating appropriate principles to serve as means to agreed-upon ends." Id. at 96.

45. See infra Part IV.B. 
Clause doctrine. For some, the dominant doctrine during the 1970s and 1980s was separationism. ${ }^{46}$ Professor Ira Lupu argued that this focus on separating church and state, which "required reduction in public celebration of sectarian religion," 47 had "a doctrine of secular privilege at its heart." 48 As will be discussed below, Professor Lupu's observation recognized that, at least as to government speech, there could be no neutrality between the horse and the non-horse.

Professor Douglas Laycock rejected the idea that separationism was opposed to neutrality. Indeed, he has argued that there is a fundamental goal behind both ideas: the minimization of government influence over the religious choices of individuals - a goal he labels "substantive neutrality." 49 He identifies two different theories of neutrality as competing for dominance within Supreme Court cases that deal with the concept: "no-aid" and "nondiscrimination." 50 The former, which he finds originating in the debate over public financing of churches in the eighteenth century, ${ }^{51}$ requires that the government provide no benefit to religion. He finds this to be the predominant strand in the logic of Lemon, particularly its second prong. ${ }^{52}$ The neutrality that the Establishment Clause requires, in this theory, is inactivity: "doing nothing neither helps nor hurts religion." 53

The neutrality of the nondiscrimination principle, which Laycock finds demonstrated in-but not created by ${ }^{54}$-Widmar $v$. Vincent, ${ }^{55}$ prevents the government from placing a burden on religion different from that placed on nonreligion. ${ }^{56}$ The focus on "analogous secular

46. See, e.g., Carl H. Esbeck, A Constitutional Case for Governmental Cooperation with FaithBased Social Service Providers, 46 EMORY L.J. 1, 4 (1997) (Professor Esbeck refers to neutrality as separationism's "major competitor.").

47. Ira C. Lupu, The Lingering Death of Separationism, 62 GEO. WASH. L. REv. 230, 231 (1993).

48. Id. at 249 .

49. Douglas Laycock, The Underlying Unity of Separation and Neutrality, 46 EMORY L.J. 43, 69-70 (1997).

50. Id. at 48 .

51. Id.

52. Id. at 56 .

53. Id. at 48 .

54. See id. at 62-63. Laycock finds the idea to be much older, hearkening back not only to Everson but also to cases as diverse as West Virginia Board of Education v. Barnette, 319 U.S. 624, 641-42 (1943) (Jehovah's Witnesses not required to participate in public school daily flag salute), Cantwell v. Connecticut, 310 U.S. 296, 310-11 (1940) (breach of peace statute could not be used against religiously offensive speech that did not meet the "clear and present danger" standard), and even Bradfield v. Roberts, 175 U.S. 291, 291 (1899) (government not barred from contracting with hospital because of its religious identity).

55. 454 U.S. 263 (1981).

56. Laycock, supra note 49 , at 48 . 
activities"57 means that the government may neither help nor harm religions. $^{58}$ In practice, because the no-aid theory should prevent government from helping religions, the nondiscrimination theory may carry the most weight in cases where government is denying a benefit to religions. $^{59}$

Professor Laycock's theory of substantive neutrality endeavors to chart a course between these theories by tacking from one to the other rather than by purporting to sail evenly between them. By focusing on the goal of minimizing government influence upon religion, one can determine whether "substantive neutrality" means, in a particular instance, no-aid or nondiscrimination. ${ }^{60}$ For examples of the formergovernment-inactivity focus - he offers the kind of regulatory exemptions usually associated with the Free Exercise Clause. ${ }^{61}$ The latter-nondiscriminatory theory-is useful in cases where the government is exercising secular authority in a way that requires it to have contact with religious institutions, like "paying for soup kitchens." 62 In those instances, government withholding of benefits to religious institutions can be characterized as giving incentives to secularize, a far cry from a minimal role in religion for the state. ${ }^{63}$

Professor Laycock's theory, helpful in many areas, becomes somewhat inflexible when dealing with religious speech by the government. He concludes that because celebration or praise by government makes religion better off than it would otherwise be, such government action should be judged against a baseline of government inaction. ${ }^{64}$ As any government speech is less neutral than no government speech, the government should not speak at all. ${ }^{65}$ Left unanswered are the puzzling cases in which the government has spoken in the past, and

\footnotetext{
57. Id.

58. See id.

59. See id.

60. Laycock, supra note 49 , at 70 .

61. Id. at 71-72.

62. Id. at 71 .

63. See id.

64. Id.

65. See id. at 72 (" $[\mathrm{T}]$ he same rule applies in either case: government should neither praise nor condemn religion in general or any religion in particular.").
} 
evidence of that speech remains today. ${ }^{66}$ In such cases, may-or mustthe government act to remove vestiges of its former speech?

A number of scholars have even argued that neutrality does not exist. ${ }^{67}$ Professor Steven D. Smith, for example, has endeavored to show that no amount of tinkering with constitutional doctrines of religion could ever prove satisfactory. ${ }^{68} \mathrm{He}$ argues powerfully that because there is no single theory of religious freedom, current analyses of the Establishment Clause were "doomed from the start." 69 He characterizes neutrality as "illusory" because of the lack of a truly neutral vantage point from which to judge from among these alternate versions of freedom. ${ }^{70}$

Although Professor Smith's ideas are powerful and compelling, this Article stops well short of them. The idea that a view of constitutional text is utterly dependent upon the belief system of the observer is not, ultimately, cabinable. ${ }^{71}$ His argument ultimately leads, it seems to me, to an expansive critique, the refutation of which is well beyond my intentand certainly my abilities. A simple thought experiment may illustrate my point. Consider the existence of a true solipsist, convinced that his consciousness alone exists. How is one to convince that person of the importance of law without any reference to a belief system that he, by definition, does not share? ${ }^{72}$

66. There is a further difficulty in this area that arises from the juxtaposition of the First Amendment's two guarantees regarding religion. For some scholars the Establishment Clause and the Free Exercise Clause work together to create "religious liberty," and maintain that the same test should be used for both. See, e.g., Laycock, supra note 49, at 45-46; Esbeck, supra note 46, 27-28; Lupu, supra note 47, at 256-79. The Supreme Court has not historically shared this approach, and this Article will proceed with the assumption that Free Exercise doctrine has little light to offer on the permissibility of government religious displays.

67. Others acknowledge that it does exist, but is "ambiguous, sometimes irresolvably so." John T. Valauri, The Concept of Neutrality in Establishment Clause Doctrine, 48 U. PITT. L. REV. 83, 92 (1986). Although not rejecting the concept as Professor Smith does, Professor Valauri suggested that the indeterminacy of neutrality "reflects an underlying disagreement about the basic standards of evaluation." Id. at 93.

68. See Steven D. Smith, Foreordained Failure: The Quest for a Constitutional PRINCIPLE OF RELIGIOUS FREEDOM 5 (1995) (“[N]o amount of rethinking, however meticulous or energetic, is likely to improve the situation as long as we insist on pressing the same bad questions."). For a thoughtful example that continues this line of argument, see Frank S. Ravitch, $A$ Funny Thing Happened on the Way to Neutrality: Broad Principles, Formalism, and the Establishment Clause, 38 GA. L. REV. 489 (2004).

69. SмITH, supra note 68, at 16.

70. Id. at 97 .

71. Indeed, Professor Smith reports being told by early reviewers of his work that "the claims ... extended well beyond the First Amendment's religion clauses." Id. at v.

72. This is not as far a rhetorical stretch as might be assumed. To argue that everything depends on perspective, Professor Smith quotes Oliver Cromwell as supporting "freedom of conscience" while prohibiting the celebration of the mass. Id. at 8. By raising Cromwell to an example of one view, among many, of religious liberty, he demonstrates the breadth of his 
The notion that nothing can occupy a midpoint between a horse and all things that are not horses is a good deal smaller than the argument that all positions rely on underlying, and hence untestable, predispositions of truth. $^{73}$

\section{Impossibility and Logic}

If the initial hypothesis of this Article is correct - that neutrality is problematic - then it is especially problematic in religious speech cases. The difficulty is not that the boundaries have been poorly drawn, nor even that the available tests have failed to show the proper location of the boundaries. The problem is insoluble: a particular government action must be either religious or irreligious. If nothing can be neutral between a horse and a non-horse, then surely nothing can be neutral between religion and nonreligion. Indeed, this view may well inform some of those who seek "neutrality," but a neutrality that persistently tilts to the nonreligious side of the balance.

Of course, such forces are not likely to go unmet in a robust discussion in a democratic society, and indeed, they do not. Some scholars (and even judicial figures ${ }^{74}$ ) have responded that neutrality, as articulated in Lemon, reflects an attitude that dismisses religion-religion that merits a place, perhaps even a privileged place, in the American system. $^{75}$ Such scholars frequently echo the observations of the most celebrated observer of the young United States, who argued in 1840 that "belief is more necessary" to people living in a democracy "than to all others." $" 76$

enterprise.

73. Unlike the Professor Smith attack, this concern about neutrality does leave room for solutions. This, after all, was the challenge-and-response posed a quarter-century ago by Judge Bork in his argument that " $[\mathrm{t}]$ here is no principled way to decide that one man's gratifications are more deserving of respect than another's." Robert H. Bork, Neutral Principles and Some First Amendment Problems, 47 IND. L.J. 1, 10 (1971). Judge Bork's solution to this litigation difficulty was to limit rights to those "the framers actually... intended and which are capable of being translated into principled rules" as well as those "located in the individual for the sake of a governmental process that the Constitution outlines." Id. at 17.

74. This viewpoint is held by at least one Justice. See Thomas B. Colby, A Constitutional Hierarchy of Religions? Justice Scalia, the Ten Commandments, and the Future of the Establishment Clause, 100 Nw. U. L. REV. 1097, 1105, 1139 (2006) (arguing that Justice Scalia's dissent in McCreary County is "an all-out assault on the venerable principle of neutrality," and that his understanding "aligns almost perfectly with the political preferences of the Republican Party").

75. Patrick M. Garry, Religious Freedom Deserves More than Neutrality: The Constitutional Argument for Nonpreferential Favoritism of Religion, 57 FLA. L. REV. 1, 33 (2005) ("Neutrality ignores the special value of religion ....").

76. AleXIS DE TOCQUEVILle, DEMOCRACY IN AMERICA, 154 (Henry Reeve trans., rev. ed., vol. II, Colonial Press 1899). De Tocqueville felt that the greatest danger to a democracy was 
Indeed, there have been moments that caused the Supreme Court to fear that a doctrine of neutrality in reality drew them into the position of choosing between two opposing sides with no real neutral ground between them. Justice Hugo Black, often thought of as the developer of the neutrality doctrine, ${ }^{77}$ expressed some concern on this very point two decades later. ${ }^{78}$ In the context of a state statute prohibiting the teaching of evolution, the Court focused on the fact that the legislature had "select[ed] from the body of knowledge a particular segment which it proscrib[ed] for the sole reason that it is deemed to conflict with ... a particular interpretation of the Book of Genesis by a particular religious group." 79 That much was certainly true. ${ }^{80}$ Of course, the reverse was true as well, which troubled Justice Black. If, in fact, Darwinian evolution was "anti-religious," how could its teaching be neutral? ${ }^{81}$ Indeed, critics of neutrality theory can point to the dilemma that bothered Justice Black to show this seemingly self-contradictory feature of the pursuit of neutrality. ${ }^{82}$

The Epperson dilemma arises from the fundamental difficulty of neutrality as a guiding principle for courts in cases requesting injunctions: there can be no neutral position between the litigants. At the end of the case, the court must decide. It may grant the injunction, or it may deny it. It can allow the state to prohibit the teaching of evolution, or it can forbid the state from doing so. It cannot do both, and there is no neutral position between the horses and non-horses of allowing and forbidding. ${ }^{83}$

unchecked materialism, as "[d]emocracy encourages a taste for physical gratification." Id. Therefore it did not matter to the Frenchman what the particular religious beliefs were: "[T]he community would run less risk of being brutalized by believing that the soul of man will pass into the carcass of a hog, than by believing that the soul of man is nothing at all." Id. at 155 .

77. See Everson v. Bd. of Educ., 330 U.S. 1, 18 (1947) (Justice Black stated, "[The First] Amendment requires the state to be a [sic] neutral in its relations with groups of religious believers and non-believers ...."); see also discussion supra Part II.A.

78. Epperson v. Arkansas, 393 U.S. 97, 109 (Black, J., concurring).

79. Id. at 103 (majority opinion).

80. Arkansas adopted the statute at issue in response to the Scopes Monkey Trial. Id. at 98.

81. Id. at 113 (Black, J., concurring). Black accepted the notion that the teaching of evolution was anti-religious, and therefore proposed that the removal of both evolution and creationism from the classrooms would "leave the State in a neutral position." Id. This approach was rejected by the Supreme Court in Edwards v. Aguillard, 482 U.S. 578, 593-94, 596 (1987).

82. See, e.g., SMITH, supra note 68, at 83. Professor Smith constructs a pair of syllogisms from the case showing that the Constitution both compels and prohibits the teaching of evolution in public schools.

83. If there was any requirement for further chaos, it could be supplied by Kaufman $v$. McCaughtry, 419 F.3d 678 (7th Cir. 2004), which found a violation of the Establishment Clause when a prison disallowed the formation of an atheist study group. Agreeing that the government may accommodate religion while not accommodating nonreligion, the court nonetheless barred the government action because "atheism is Kaufman's religion." Id. at 684. When atheism is itself, in 


\section{The Ten Commandments Cases}

A pair of cases argued together in March 2005, gave rise to a hope that the Supreme Court intended to sort out Establishment Clause chaos in the area of symbolic government speech. The Court granted certiorari on two challenges to government display of the Ten Commandments in disparate settings. In Austin, Texas, the twenty-two acre lawn surrounding the state capitol building was dotted with almost forty markers and monuments. ${ }^{84}$ Among them stood a Ten Commandments monument that the Fraternal Order of Eagles (FOE) had funded in $1961 .^{85}$ Nearly forty years later and a thousand miles away, officials in Kentucky's Pulaski and McCreary counties hung framed copies of the Ten Commandments on the inside walls of their courthouses. ${ }^{86}$ I suspect that I was not alone in thinking that the pairing of these two cases was a boon for legal clarity. The Court seemed likely to divide the two cases, allowing only one of them to stand, and offer a consistent rationale that would demonstrate the difference between the two. ${ }^{87}$

Sadly, this was not to be. Rather than adopting consistent principles, the lead opinions in the two cases took contradictory views of both test and result. The Court in McCreary County used the traditional Lemon analysis to find that the display was improper. ${ }^{88}$ The Court said the display had "a predominantly religious purpose." 89 The Court addressed the purpose of the current arrangement of documents - a potpourri called "The Foundations of American Law and Government Display" — within the context of the two displays which had come before it. ${ }^{91}$ The first consisted only of the Ten Commandments. ${ }^{92}$ By contrast, because the

religious terms, a horse, one can only wonder if anything can even qualify as a non-horse.

84. Van Orden v. Perry, 545 U.S. 677, 681 (2005).

85. Id. at 681-82.

86. McCreary County v. ACLU of Ky., 545 U.S. 844, 851 (2005).

87. Indeed, two years earlier the Court had done precisely this with equal protection challenges to affirmative action in a pair of cases involving the University of Michigan Law School and the College of Literature, Science, and the Arts of the same university. Compare Grutter v. Bollinger, 539 U.S. 306 (2003), with Gratz v. Bollinger, 539 U.S. 244 (2003).

88. 545 U.S. at $859-63$.

89. Id. at 881 .

90. Id. at 856. The display consisted of not only the Ten Commandments, but also "framed copies of the Magna Carta, the Declaration of Independence, the Bill of Rights, the lyrics of the Star Spangled Banner, the Mayflower Compact, the National Motto, the Preamble to the Kentucky Constitution, and a picture of Lady Justice." Id. The state constitution preamble would seem to be included because it, like everything else on the list except the Bill of Rights and the picture, contains an overtly religious reference. See KY. CONST. pmbl. ("We, the people of the Commonwealth of Kentucky, grateful to Almighty God for the civil, political and religious liberties we enjoy .....”).

91. McCreary County, 545 U.S. at 868-69.

92. Id. at 851 . 
second consisted of the Ten Commandments surrounded by other overtly religious documents, ${ }^{93}$ the Court had no difficulty in determining that the county's purpose was not educational or historical, but religious. ${ }^{94}$ The author of the opinion, Justice Souter, referred to the companion case from Texas only once - and that was to repeat a pro-separation comment from James Madison that Justice Stevens quoted in his dissent in Van Orden. ${ }^{95}$ The Court's opinion in McCreary County brought forth a fierce dissent by Justice Scalia, who cited to the plurality opinion in Van Orden a handful of times ${ }^{96}$ and once to the concurrence by Justice Breyer. ${ }^{97}$ The great preponderance of Scalia's discussion of the Texas case, though, was to the dissent by Justice Stevens, which he claimed was "largely devoted to an attack upon a straw man."

Justice Scalia's view of neutrality, given voice in the dissent, was that neutrality among sects was required in public funding cases, but that favoring religion over irreligion was constitutional. ${ }^{99}$ Indeed, pointing to the string of cases where the Court allowed practices that benefited religion, Justice Scalia suggested that history was an inappropriate support for any practice that would otherwise violate the Constitution. ${ }^{100}$ Instead, he suggested that the Court in those cases backed away from neutrality out of fear of backlash. ${ }^{101}$ In short, there is no hint from any

93. Id. at $853-54$. The second display included the following:

$[\mathrm{T}]$ he 'endowed by their Creator' passage from the Declaration of Independence; the Preamble to the Constitution of Kentucky; the national motto, 'In God We Trust'; a page from the Congressional Record of February 2, 1983, proclaiming the Year of the Bible and including a statement of the Ten Commandments; a proclamation by President Abraham Lincoln designating April 30, 1863, a National Day of Prayer and Humiliation; an excerpt from President Lincoln's 'Reply to Loyal Colored People of Baltimore upon Presentation of a Bible,' reading that ' $[\mathrm{t}] \mathrm{he}$ Bible is the best gift God has ever given to man'; a proclamation by President Reagan marking 1983 the Year of the Bible; and the Mayflower Compact.

Id. at 854 (citations omitted).

94. Id. at 881 .

95. Id. at $878-79$.

96. See, e.g., id. at $905 \mathrm{n} .10$ (Scalia, J., dissenting) (referring to the "undeniable historical meaning" of the Ten Commandments as "a symbol of the religious foundations of law").

97. Id. at 908 .

98. Id. at 895 .

99. Id. at $892-93$.

100. Id. at 892 .

101. Id. at $892-93$ ("What, then, could be the genuine 'good reason' for occasionally ignoring the neutrality principle? I suggest it is the instinct for self-preservation, and the recognition that the Court, which 'has no influence over either the sword or the purse' cannot go too far down the road of an enforced neutrality that contradicts both historical fact and current practice without losing all that sustains it: the willingness of the people to accept its interpretation of the Constitution as definitive ...." (citations omitted)). 
opinion in McCreary County that a predictable doctrine governed both cases.

This jurisprudential isolationism continued in the companion case. The plurality opinion in Van Orden made no mention whatsoever of the seemingly inconsistent result in the Kentucky case, a fact noted by Justice Thomas in his concurrence. ${ }^{102}$ The plurality found that the Lemon test was "not useful"103 in this context. Instead, Chief Justice Rehnquist's opinion asserted that "[s]imply having religious content or promoting a message consistent with a religious doctrine does not run afoul of the Establishment Clause."104 This, in turn, spawned the abovementioned dissent by Justice Stevens, but did not give rise to the kind of cross-reference that would allow readers to find a dispositive understanding of the combined meaning of these cases.

Like the Michigan affirmative action cases of two years earlier, the Ten Commandments cases of 2005 were a pair of 5-4 decisions in which only one Justice was in the majority on both cases. Unlike Gratz and Grutter, however, that Justice did not author one of the principle opinions, thus severely limiting the consistency of the results. ${ }^{105}$ Indeed, Justice Breyer, in providing the critical fifth vote in Van Orden, concurred only in the result. Far from the Michigan solution of articulating a test and finding that one set of facts passed and the other failed, the Ten Commandments cases of 2005 left us with two conflicting sets of outlooks upon closely related circumstances. They are very useful in arguing for a desired result, but less so if one seeks guidance to the Supreme Court's view of the correct answer in a particular case.

For example, one can look to the majority in McCreary County and discover principles by which to evaluate government speech. One could use Lemon's purpose prong to guarantee neutrality. ${ }^{106}$ If the purpose was not neutral - if the government sought to favor religion - a court could find the government action unconstitutional. This look at purpose is not

102. Van Orden v. Perry, 545 U.S. 677, 697 (2005) (Thomas, J., concurring) ("The inconsistency between the decisions that the Court reaches today... only compounds the confusion.").

103. Id. at 686 (plurality opinion).

104. Id. at 690 .

105. It may well be that the presence of Justice O'Connor in both majorities was responsible for the acknowledgement of Grutter in Gratz: "Petitioners further argue that 'diversity as a basis for employing racial preferences is simply too open-ended, ill-defined, and indefinite to constitute a compelling interest capable of supporting narrowly-tailored means.' But for the reasons set forth today in Grutter v. Bollinger (citation omitted), the Court has rejected these arguments of petitioners." Gratz v. Bollinger, 539 U.S. 244, 268 (2003).

106. McCreary County, 545 U.S. at 860. 
threatening because it is what courts frequently do. ${ }^{107}$ However, the court need not worry about whether the government officials have sinister motives in their hearts when they act, because the key to understanding the purpose prong is Justice O'Connor's endorsement test, which is concerned with public expression of governmental intent. ${ }^{108}$

If one is displeased with this relatively restrictive approach to government religious speech, one could turn instead to the plurality in Van Orden. There we learn that the Lemon test is "not useful in dealing with the sort of passive monument that Texas has erected on its Capitol grounds." religious, ${ }^{110}$ but the Supreme Court's "opinions, like our building, have recognized the role the Decalogue plays in America's heritage." $" 111$ Because the Ten Commandments have a "dual significance," representing both religion and government, the opinion of Chief Justice Rehnquist would always allow them. There is simply nothing in his opinion that allows the reader to reconcile it with the simultaneous majority opinion of Justice Stevens in McCreary County.

One is inclined to throw up hands in an expression of disbelief: to recognize these opinions as equally valid is to find a horse that is also a non-horse. This will not do. However, there may be a way out. Professionals in other fields have faced the problem of reconciling seemingly opposite and simultaneous ideas. In the last century, it was the physicists, not the lawyers, who had to confront this quandary, as they faced the fact that subatomic particles were also, contradictorily, waves.

\section{A BRIEF DETOUR INTO THE ODD WORLD OF QUANTUM MECHANICS $^{113}$}

A paradigm shift of extraordinary size occurred in the world of physics over the last one hundred years. Perhaps unsurprisingly, it has

\footnotetext{
107. See id. at 861 ("[It] is a staple of statutory interpretation that makes up the daily fare of every appellate court in the country.").

108. See id. at 863 ("A secret motive stirs up no strife and does nothing to make outsiders of nonadherents ....").

109. Van Orden, 545 U.S. at 686 (plurality opinion).

110. Id. at 690 .

111. Id. at 689 .

112. Id. at 692 .

113. I am not a physicist. My (limited) understanding in this section is gleaned solely from texts designed for laymen, and discussion with some very patient physicists. Despite their generally high quality, I may be horribly wrong. I apologize to anyone who understands this area better than I and grimaces at my overgeneralizations.
} 
made little impact in the worldview of most non-physicists, ${ }^{114}$ despite the extraordinary changes it has wrought in all of our lives. The discovery of quantum mechanics, its formulation in a series of mathematical models that have proved constant and accurate, and the inability of the community of scientists to agree on just what underlying reality was signified by the equations, forms a story that is both compelling and too complex to be told here. Two particularly famous experiments, though, shed some light on the fundamental conundrum of what might be called the philosophical difficulty of quantum mechanics. It is this difficulty, in turn, that may help us reach a new understanding of the Establishment Clause.

\section{A. What Matters is Measurement}

\section{The Stern-Gerlach Device}

One of these experiments concerns the Stern-Gerlach device, which involves the use of magnets to affect the trajectories of particles. A Stern-Gerlach device is a pair of magnets, one with north polarity and the other south, facing each other. The device operates because of the internal magnetic property, or "spin" of objects. This pair of magnets affects the paths of things fired between them, causing them to bend toward one magnet and away from the other in degrees dependent upon their direction and velocity of spin. ${ }^{115}$

In 1921, when Professors Stern and Gerlach tried out their apparatus on silver atoms, they discovered a wholly unexpected result. The device deflected the atoms into two - and only two-paths. The beam fired through the Stern-Gerlach device would split into two beams: one beam deflecting toward the north polarity magnet, the other beam deflecting toward the south polarity magnet. The result was incontrovertible and consistent in repeated tests. ${ }^{116}$ Physicists used the device for further trials with electrons, the negatively charged sub-atomic particles. Any oddities in the silver trials caused by the internal structure of the atom were thus eliminated. ${ }^{117}$ Electrons behaved in precisely the same way as the silver

114. After all, discoveries made centuries ago have not completely restructured the way that we talk - and perhaps think - about reality. I still refer to the sun rising, even though I know better. I do not believe that I am alone in doing so.

115. DAVID Lindley, Where Does the WeIRDNess Go? Why QuANTUM Mechanics IS STRANGE, BUT NOT AS STRANGE AS YOU THINK 9 (1996).

116. Max Jammer, The Conceptual Development of Quantum Mechanics, in 12 THE HISTORY OF MODERN PHYSICS 1800-1950, at 131 (2d ed. 1989).

117. DAVID WiCK, ThE INFAMOUS BOUNDARY: SEVEN DECADES OF CONTROVERSY IN 
atoms. They apparently did not have wildly different axes and rates of spin; they were not like little baseballs thrown in the air-some curves, some fastballs, and the occasional knuckleball. Whatever they had that passed for spin occurred in only two forms (labeled, for convenience if not accuracy, "up" and "down"). No matter how many times the electron beam traveled through the Stern-Gerlach device, the result was the same: the up electrons went to one area and the down electrons to another. ${ }^{118}$ The result was difficult to explain, but at least it was simple.

Or so it seemed at first. The series of Stern-Gerlach experiments gave constant results when the device was rotated ninety degrees. The beam of electrons would still split into two equal beams when leaving the device, whether it was perpendicular to the earth's surface or parallel: the two beams would themselves always be parallel to the magnets in the apparatus, so the twin beams could be made to rotate a full circle by rotating the Stern-Gerlach device on its axis. This demonstrated that the magnets, and not any intrinsic property of the initial beam, caused the result. ${ }^{119}$

Things became more complex, though, as other Stern-Gerlach devices were added in series. When a second device was placed along the line of one of the two beams exiting the first apparatus, no electron changed its behavior. Fifty percent of the electron stream exited the first apparatus by going up and all came through the second apparatus still going up. This was unsurprising. There was no reason why any particular electron having an up spin should change. The same conventional result occurred with the down spin electrons. ${ }^{120}$

Matters grew more curious when the second device was set perpendicular to the first along one of the beams. Fifty percent of the electrons went in, all happily demonstrating their up spin. In this second device they would be sorted again, but could only emerge, if the pattern held, left and right. That is what they did, and in equal numbers. Whatever the "spin" of electrons might represent, they would travel between the magnets and split into two beams in equal numbers, regardless of having demonstrated a different spin only an instant before. $^{121}$

The problem approached the level of a Zen koan when the scientists placed a third Stern-Gerlach device onto one of the left or right beams,

\footnotetext{
QUANTUM PHYSICS 13 (1995).

118. LiNDLEY, supra note 115, at 17.

119. Id. at 18 .

120. Id.

121. Id. at 18-20.
} 
parallel to the original apparatus. Now the entirety of the second beam emerged again, this time split into equal parts of up and down electrons.

This, if contemplated conventionally, makes no sense. Half of the electrons, the down spinners, were weeded out by the first machine. The second showed that all of those that remained were capable of showing a left or right bias. The third now showed that either the left or right spinners were capable of splitting, fifty-fifty, into up and down spinners. To confirm the puzzling result, Stern and Gerlach removed the second device. The electrons complied with their prior (bewildering) behavior: all of the up spin electrons went up again as they exited the second machine. An up-down spin, once measured, remained constant. Reinstallation of the middle device renewed the paradox: a left-right spin, once measured, restored the uncertainty of the up-down spin even in those electrons that had been confirmed up-spinners an instant before. $^{122}$

Difficult arguments among unsatisfactory options occurred over what these results meant. Before examining them, and considering their impact on legal thinking, it is worth looking at the other paradigmatic problem presented by quantum mechanics.

\section{Light and the Two Slits}

Professor Richard Feynman was fond of saying that the most critical thing to understanding quantum mechanics was the experiment with the two holes, because it was "impossible, absolutely impossible, to explain in any classical way ...." At first glance, it seems to reflect a very different problem from the Stern-Gerlach apparatus. Upon further consideration, they suggest the same conclusion.

The two-slit experiment works as follows. Photons of light are emitted from a source into a box which contains only two exit slits. Departure through them will leave the photons in a second box, with a collecting apparatus on the far wall to determine where they strike. After the experiment, the collector displays an interference pattern, a series of overlapping lights and darks that show where the two light waves affected one another. ${ }^{124}$

As before, the result is not surprising at first. We are familiar in our daily life with the notion of wave interference. Anyone who has ever

122. Id.

123. JOHN GRIBBIN, In SEARCH OF SCHRÖDINGER'S CAT: QUANTUM PHYSICS AND REALITY 164 (1984).

124. WICK, supra note 117 , at 40. 
dropped two things into a pool of water has seen that the ripples created a pattern where the crests and troughs either coincide and magnify each other or cancel each other out because of their opposition. We know that light travels in waves and expect that it would show the same sort of wave interference pattern that water would. ${ }^{125}$

The difficulty comes when one hole is covered. Suddenly the light does not behave like a wave. Now it acts as if it were a particle, as if, to use Professor Feynman's example, it were a machine gun firing bullets through the slit. ${ }^{126}$ There is no wave pattern formed on the collector wall when there is only one slit; instead, the light concentrates in one place. Professor Feynman's metaphor holds true; we certainly expect that bullets would behave the same way. However, the wave interference pattern reappears when the second slit is reopened. ${ }^{127}$

Things get very odd when the emitter is slowed down to release only one photon at a time. If one slit is open, each photon will act as a bullet as it travels; it will concentrate on the area of the detector opposite the slit. If both are open, however, each photon will act as if it were part of a wave, even if it is released by itself. Electron by electron, the interference pattern that can only be caused by waves will gradually appear on the collector. ${ }^{128}$ This, of course, makes no sense. It seems logical that any particular electron, even if both slits are open, must go through only one of them. When it does that, it should behave as a particle, whether or not the other slit is open. ${ }^{129}$

Things grow worse. Physicists discovered a way to force the photons to replicate the bullet pattern rather than the wave pattern on the collector, even though both slits are open. The technique requires placing detecting mechanisms on the slits. ${ }^{130}$ Once we know through which slit an electron passes, it will behave as a particle that has passed through that slit. Turn off the detector, so we do not know, and the interference pattern returns.

\footnotetext{
125. GRIBBIN, supra note 123 , at $165-66$.

126. Id. at $168-69$.

127. Id.

128. Id. at $170-71$.

129. Id. at 170 .

130. Id. at 171. The same result occurs if one places the entire apparatus in a Wilson cloud chamber, which shows the contrails of particular particles. WICK, supra note 117, at 42 .
} 


\section{B. "Do You Really Think the Moon is Only There When You Look at It? ${ }^{, 131}$}

Albert Einstein famously rejected quantum mechanics, which in his view posited a cosmological game of chance. ${ }^{132}$ He spent a great deal of time and energy trying to explain both the two-slit experiment and the Stern-Gerlach experiment in a way that made sense classically. His projects failed. Ultimately Einstein himself could not resolve the difficulty of electrons that seemed to change their minds about spin, or about photons that seemed to know whether the other slit was open or not.

His question about the moon was in response to the philosophical position taken by Neils Bohr and what came to be called "the Copenhagen School."133 Bohr argued that the only way to understand quantum paradoxes was to recognize that there was no underlying reality of the measured quantity independent of the measurement. ${ }^{134}$ Bohr claimed that as long as one could not know through which slit a particular photon traveled, there was only a probability that the photon went through one slit or the other. As probability appears in waves, the wave pattern on the collector was perfectly logical. The moment that an observer confirmed that a photon went through a particular slit, either by monitoring it or through the simple expedient of closing the other, the probabilities for the photon collapsed into a single discrete event. The probability, in other words, does not represent a limit of our knowledge about what is really happening; the probability is what is really happening. ${ }^{135}$

The same is true of the Stern-Gerlach device: as long as the spin of the electrons has not been determined by the apparatus, it exists only as a probability. Once the device has measured it, by forcing it into a dichotomy of up or down, it is set-at least until a left-right measurement commits the electrons to that choice and so reestablishes the up-down uncertainty. The problem, the Copenhagen School asserts, is that we tend to think that measurement is a determination of the facts of an underlying reality. There is in fact no underlying reality,

\footnotetext{
131. WICK, supra note 117 , at xi.

132. "The great initial success of quantum theory cannot convert me to believe in that fundamental game of dice," Einstein noted. Jammer, supra note 116, at 156.

133. The Copenhagen School, or Copenhagen Interpretation, derived its name from a certain school of thought; its chief interpreter, Neils Bohr, being headquartered in Copenhagen. See THANKAPPAN, supra note 7 , at 448.

134. Jammer, supra note 116 , at 363.

135. Richard FeynMAn, THE CHARACTER OF PHYSICAL LAW 145 (1965).
} 
Copenhagen adherents argue, only a set of possible outcomes with assorted probabilities. There is certainty only when there is measurement and the probabilities collapse to a single measurable event. ${ }^{136}$ Bohr, of course, never argued that the moon disappeared when he stopped looking at it. Indeed, modern defenders of the Copenhagen School have explained that this underlying reality at the subatomic level does not disrupt our daily lives because the constant interaction of particles functions, essentially, as a form of measurement. ${ }^{137}$ Each collision causes the collapse of possibilities, and so a stability exists in the world we know which is different from the chaos that we now know lurks just out of sight.

Nevertheless, the primary insight of the Copenhagen School, that there is no reality independent of the measurement of reality, is worth considering further. It is precisely the observation that may provide a way out of Chuang Tzu's conundrum, and may offer a valuable new way to consider the Establishment Clause.

\section{COPENHAGEN AND THE ESTABLISHMENT ClAUSE}

If the Copenhagen School is correct, it may yield an answer to the puzzle Chuang Tzu presented to us. The Copenhagen approach notes that we cannot remove the mechanics of measurement from questions about reality. A particular quantity does not exist in the real world, awaiting its quantification by some measuring device. Instead, the world is made up of a series of probable occurrences, which are only reduced to certainty by the fact of being measured.

The same may be true of the Establishment Clause. In the area of government speech, our usual mode of discussion is to treat the underlying government action as if it does, or does not, violate the Establishment Clause. If some potential plaintiff believes that it does, that person sues the government, asking the court to stop it from continuing the kind of speech which violates the Constitution. The government actor responds that the speech in question is constitutionally permitted, either because it meets some test or combination of tests, or because it falls into some poorly-defined but historically-permitted set of permissible exceptions. The court then decides, generally while announcing its intent to remain neutral between religion and nonreligion. This might be called the classical model of thinking about the

136. WICK, supra note 117, at 148-49.

137. See, e.g., LINDLEY, supra note 115, at 198 (citing the phenomenon called "decoherence"). 
Establishment Clause. As we have seen in the cases and the scholarly literature, this model satisfies few.

A Copenhagen model would be quite different. A government action could not meaningfully be described as complying with or violating the Establishment Clause until it was decided, or measured, by a court. The court's decision could then no more be separated from the deciding than an electron's spin from its Stern-Gerlach device.

In this model, the court would recognize that it is part of the system, not a detached and disinterested observer. As noted by Justice Black, there is no way for the court to avoid taking a position in favor of one side or the other. ${ }^{138}$ Once the court has ruled, the government speech will either violate the Establishment Clause or it will not. The court's decision, then, becomes a part of the underlying question, in ways that courts typically decline to recognize. ${ }^{139}$

At some level the Copenhagen understanding appears also in the reaction of American citizenry to the acts of courts. Profoundly realist in their outlooks, Americans shower the courts, especially the Supreme Court, with letters, with protests, and with commentary. Much of it is harsh, vindictive, and unfair. ${ }^{140}$ All of it, though, reflects the underlying assumption that the law is what the Court decides. ${ }^{141}$ The Court is not, in the public eye, announcing an underlying and inevitable reality; the Court is announcing its decision. Indeed, in the context of government speech, it seems difficult, if not impossible, to separate the action of the Court, a body of government, from the message being sent.

This Copenhagen model, then, would require courts to acknowledge their own role in the process, and admit that their actions cannot be neutral between religion and nonreligion. They will never, despite their best intentions, find the neutrality which they seek. They must decide either to allow the particular government action or forbid it. The result must logically favor either religion or nonreligion.

\footnotetext{
138. See cases cited supra note 81 and accompanying text.

139. Such an idea is already present in our legal system. In adjudicating criminal liability, after all, the plea that is opposite to a "guilty" plea is not "innocent," but "not guilty." We acknowledge in so doing that the term "guilty" is not a statement of preexisting fact, but a legal conclusion to be determined by a competent authority.

140. Some of it is merely perplexing. I once had the good fortune of seeing a gentleman with a sign protesting on the sidewalk of the Supreme Court. He was upset, it turned out, because his automobile had been repossessed, and his letters to the Supreme Court had failed to get it returned.

141. Some political leaders share this assumption. Senator Mitch McConnell's opposition to campaign finance reform has always been based on the argument that the Supreme Court has equated money to speech. See, e.g., Lawrence M. O'Rourke, Campaign Reform Now Law; Opponents Swiftly File Two Lawsuits Challenging Rules, CHI. Sun-Times, March 28, 2002, at 24.
} 


\section{A. Justice Breyer's Ruminations}

Perhaps the Copenhagen School provides some understanding of Justice Breyer's much maligned opinion in Van Orden. Because he provided the critical fifth vote preserving the Austin monument, some scholars have suggested that his "particular brand of pragmatism" was "seriously counterproductive," ${ }^{142}$ or just plain wrong. ${ }^{143}$ With a Copenhagen interpretation, however, one could view his opinion as recognizing the fact that the decision of the Court was inextricably part of the government message. His opinion is therefore not only defensible, but truly insightful. It is true that he refers frequently to the lack of consistent standards ${ }^{144}$ and the necessity for judges to make individualized decisions. ${ }^{145}$ It is also true, though, that he turns time and time again to history, ${ }^{146}$ to the years without agitation concerning the Austin monument, ${ }^{147}$ and to the need to avoid a version of "neutrality" that would require the removal of longstanding evidence of religion in the public square. ${ }^{148}$

One might say that this makes no sense. A monument is a monument, and a new resident in Austin will have no idea whether the monument was erected a half-century ago or a month ago. ${ }^{149}$ There is, though, the difference recognized by a Copenhagen interpretation. A decision to leave an old monument, if phrased in terms of history, provides no justification to erect new monuments. No reader could fairly conclude from Justice Breyer's opinion that putting up new granite monuments of the Ten Commandments would survive an Establishment Clause challenge. ${ }^{150}$ On the other hand, a decision requiring its removal

142. William Van Alstyne, Ten Commandments, Nine Judges, and Five Versions of One Amendment-The First ("NOW WHAT?”), 14 WM. \& MARY BILL RTS. J. 17, 25 n.24 (2005).

143. See, e.g., Erwin Chemerinsky, Why Justice Breyer Was Wrong in Van Orden v. Perry, 14 WM. \& MARY BiLl RTS. J. 1, 3 (2005).

144. See Van Orden v. Perry, 545 U.S. 677, 699 (2004) (Breyer, J., concurring) (“[T]he Court has found no single mechanical formula that can accurately draw the constitutional line in every case.").

145. See id. at 700 ("I see no test-related substitute for the exercise of legal judgment.").

146. Id. at 701 .

147. Id. at 702 .

148. Id. at 699 .

149. See, e.g., Susan Hanley Kosse, A Missed Opportunity to Abandon the Reasonable Observer Framework in Sacred Text Cases: McCreary County v. ACLU of Kentucky and Van Orden v. Perry, 4 FIRST AMEND. L. REV. 139, 170 (2006) ("[M] ost observers will probably not know the age of the display forcing courts to create yet another fiction to find such knowledge.”).

150. Indeed, Justice Breyer specifically warned against this interpretation. See Van Orden, 545 U.S. at 703 (Breyer, J., concurring) ("[A] more contemporary state effort to focus attention upon a religious text is certainly likely to prove divisive in a way that this longstanding, pre-existing 
by bulldozer or backhoe would greatly encourage challenges to other such monuments. Justice Breyer's decision, had it been concurred in by a majority of the Court, would have gone far toward establishing a ceasefire in the nation's on-going religious battles. Because it is a decision of one, though, the Copenhagen clarity it offers is not particularly available to lower courts.

\section{B. The Chaos that Exists}

As noted above, ${ }^{151}$ the Supreme Court's Ten Commandments cases did not offer reconcilable principles of constitutional law. The resulting doctrinal confusion was predictable. Lower courts applying Van Orden and McCreary County have shown little ability to combine ideas that the members of the Court themselves were unable to reconcile. The string of cases to date following Van Orden and McCreary County have exhibited no consistency the author can discover: the judges select quotes from one of the lead opinions in either the Texas or Kentucky case, paying little more attention to the other of the pair than those lead opinions themselves did. People have challenged a wide range of government religious expression in the lower courts, and the responses have been as chaotic as one might have expected.

\section{Other Fraternal Order of Eagles Monuments}

The first fertile field of decisions arose concerning monuments identical to the one in Texas. As Justice Stevens noted in his dissent in Van Orden, the Austin monument was not unique; it was part of a very large family. ${ }^{152}$ The monuments sponsored by the Fraternal Order of Eagles came under fire in locales as diverse as Washington ${ }^{153}$ and Indiana. ${ }^{154}$ Indeed, many of these challenges had arisen before or during the Van Orden litigation, ${ }^{155}$ and the lower courts had prudently awaited

monument has not.").

151. See supra Part II.D.

152. Van Orden, 545 U.S. at 713 (Stevens, J., dissenting) (referring to hundreds of replicas of the monument provided by the combined effort of the Fraternal Order of Eagles and Cecil B. DeMille, director of The Ten Commandments).

153. Card v. City of Everett, 386 F. Supp. 2d 1171 (W.D. Wash. 2005).

154. Russelburg v. Gibson County, No. 3:03-CV-149-RLY-WGH, 2005 WL 2175527 (S.D. Ind. Sept. 7, 2005).

155. See, e.g., ACLU Neb. Found. v. City of Plattsmouth, 419 F.3d 772, 774-75 (8th Cir. 2005) ("We granted [the] petition for rehearing en banc to review the District Court's determination that the City's display of the monument violates the Establishment Clause. With the benefit of the United States Supreme Court's recent decision in Van Orden v. Perry, we now reverse." (citations 
the Supreme Court's decision. Unsurprisingly, considering the outcome in Van Orden, all survived their challenges. In many cases, the courts' application of Van Orden and McCreary County was perfunctory; even in cases where courts had initially understood Lemon to require the removal of the monuments, they summarily reversed lower courts or themselves, recognizing that the similarities with the Austin monument were "virtually identical," 156 or at least "too vivid to dismiss." where significant differences might exist, as in the case of the Fargo monument that stood alone near the city building, federal courts found that the similarities among the Fraternal Order of Eagles monuments outweighed their differences. ${ }^{158}$

In one particularly thoughtful analysis of the Supreme Court precedents, a federal judge outlined his understanding of them and elegantly related them to the case before him. In dispensing with a challenge to a monument identical to Austin's in the city of Everett, Washington, ${ }^{159}$ Judge Lasnik admitted that the opinions in the Court's two Ten Commandments cases might have "mystified" the "average American."160 $\mathrm{He}$ was not at all puzzled, however: he focused on the context of the displays, "particularly [on] the length of time ... without protest."161 In allowing the monument to remain, he quoted Justice Breyer's Van Orden observation that a decision to remove a longstanding monument might only increase strife. ${ }^{162}$

In a footnote, though, he recognized the other side of the equation: "an attempt to display the Ten Commandments on public property in today's multi-religious America would likely engender an immediate challenge . . . . Such displays would be immediately divisive . . ."163

\section{Other "Foundations of American Law and Government" Displays}

The other obvious place to find the result of the mixed message of Van Orden and McCreary County is in courthouses, as other Kentucky

omitted)).

156. Id. at 775. The dissent argued that the Plattsmouth monument differed from that in Austin because the former was alone, not part of a larger display. Id. at 780 (Bye, J., dissenting).

157. Russelburg, 2005 WL 2175527, at *2.

158. Twombly v. City of Fargo, 388 F. Supp. 2d 983, 992 (D.N.D. 2005) (noting that the grassy mall in which the monument was located created sufficient secular messages in itself by being used for, inter alia, the Fargo Blues Festival).

159. Card v. City of Everett, 386 F. Supp. 2d 1171, 1173 (W.D. Wash. 2005).

160. Id.

161. Id

162. Id. at 1177 .

163. Id. at 1177 n.7 (citations omitted). 
counties as well as other communities began to erect their own displays celebrating the "Foundations of American Law and Government" (FALG). Because their predecessor failed to survive an Establishment Clause challenge, one might think that McCreary County doomed them just as surely as Van Orden saved the other FOE monuments. This has not been the case.

The majority in McCreary County focused on the purpose prong of the Lemon test, ${ }^{164}$ and found the improper effect of the displays in part from the history of the two overtly religious displays that preceded FALG displays. ${ }^{165}$ By doing so, the majority left room for even McCreary and Pulaski counties themselves to reestablish the displays, once they had sufficiently purged themselves of an improper, endorsing purpose. ${ }^{166}$ Of course, they almost immediately requested a removal of the injunction so that they might reinstall the FALG displays. ${ }^{167}$ While the litigation in those counties continues, ${ }^{168}$ other counties in Kentucky have subsequently had their displays - identical to the third display in McCreary County - blessed by federal courts because they "lack[] a similar sectarian pedigree."169 A cynical observer might think that local leadership had learned, from the McCreary and Pulaski experience, exactly what behavior the courts would be willing to tolerate, and walked boldly to the boundary. A more charitable interpretation sees the local officials as distinctly interested in the public education value of posting these displays. Indeed, a series of state legislatures have enacted or considered legislation specifically authorizing the displays. ${ }^{170}$ The courts have so far generally adopted the charitable, more permissive interpretation of county behavior. ${ }^{171}$

164. McCreary County v. ACLU of Ky., 545 U.S. 844, 861 (2005) (citing Lemon v. Kurtzman, 403 U.S. 602, $612(1971))$

165. Id. at 866 .

166. Id. at 873-74.

167. Peter Smith, Ten Commandments Cases Have Varied Results, CouRIER-J., Oct. 3, 2007, at $1 \mathrm{~B}$

168. See Bill Estep, ACLU Asks $\$ 400,000$ in Fees in Ten Commandments Case, LEXINGTON HERALD-LEADER, Sept. 6, 2008, at D1 (stating that the "case is still pending").

169. See, e.g., ACLU of Ky. v. Mercer County, 432 F.3d 624, 631 (6th Cir. 2005) ("Here, there was only one display, one authorizing measure, and one implementation, all of which demonstrate a secular purpose.").

170. By way of example, the state legislatures of South Carolina and Georgia have considered such legislation. See Yvonne M. Wenger \& Adam Parker, S.C. Might Allow Religious Displays in Public Spaces, The Post AND CourIER, Mar. 23, 2007, at A1, and GA. Code ANN. § 45-13-51 (West Supp. 2007).

171. See, e.g., Mercer County, 432 F.3d at 627 (finding nothing in the legislative history indicating a religious purpose). 


\section{The Rock in the Desert}

The pro-religious speech side of the war has not won all of its battles. In one particularly labyrinthine case, federal courts as well as Congress have spent a great deal of energy trying to settle the fate of a cross made of metal pipe on a hilltop called Sunrise Rock in the Mojave Desert. $^{172}$ A predecessor of the cross appeared, without the permission of any government agency, on federal land at least by $1934 .{ }^{173}$ Some members of the Veterans of Foreign Wars had set up a wooden cross with a small commemorative sign in memory of fallen comrades, and religious groups subsequently used the site for Easter sunrise services. ${ }^{174}$ The cross came to the notice of the government in 1999, when a Buddhist asked if he could add a stupa ${ }^{175}$ next to the cross. ${ }^{176}$ By then the original wooden cross was just a memory, replaced most recently in 1998 by an enterprising individual who drilled holes into the rock to allow the fitting of the five-foot tall white-painted metal pipe cross. ${ }^{177}$

The National Park Service rejected the stupa request and, after determining that there was neither authorization for the cross nor historical significance to it, determined to remove it. ${ }^{178}$ Congress then entered the fray, prohibiting the use of government funds to pay for removal, ${ }^{179}$ and later designating it a national memorial. ${ }^{180}$ While the challenges to the cross were still pending, Congress took the precautionary further step of authorizing the trade of the single acre containing the cross to a private owner in return for a five-acre parcel of land elsewhere. ${ }^{181}$ The owner, perhaps unsurprisingly, was the very same gentleman who had drilled the holes into the rock for mounting the current cross. ${ }^{182}$

The Ninth Circuit disallowed the land transfer, relying in large measure on a case from Oregon disapproving of a similar attempt to

172. Buono v. Kempthorne, 502 F.3d 1069, 1071-79 (9th Cir. 2007), amended and superseded on denial of reh'g, 527 F.3d 758 (9th Cir. 2008).

173. Id. at 1072 .

174. See id. (stating that the worship services became regular in 1984).

175. A stupa is a mound used for worship purposes; Buddhism integrated the practice before the advent of the Indian emperor Ashoka. SOURCES OF INDIAN TRADITION 94 (Wm. Theodore de Bary ed., 1958).

176. Buono, 502 F.3d at 1072.

177. Id.

178. Id. at 1073 .

179. Id. (citing Pub. L. No. 106-554, § 133, 114 Stat. 2763A-230 (2000)).

180. Id. (citing Pub. L. No. 107-117, § 8137, 115 Stat. $2278-79$ (2002)).

181. Id. at 1074 (citing Pub. L. No. 108-87, § 8121, 117 Stat. 1100 (2003)).

182. Id. at 1072, 1075 (identifying Mr. Henry Sandoz of Mountain Pass, California). 
convert public into private speech by making a park into private property. ${ }^{183}$ Perhaps surprisingly, the only reference to the seemingly relevant Ten Commandments cases of 2005 was the observation-in a footnote - that together they demonstrate "the need to conduct a factspecific inquiry in this area."

\section{The City of the Crosses}

The Court's conflicting observations about the Establishment Clause were apparently little more helpful in resolving the constitutionality of the appearance of three crosses on school maintenance vehicles and a student-painted mural at the Booker T. Washington Elementary School in Las Cruces, New Mexico. ${ }^{185}$ Judge Brack was able to cite them for the propositions that the term "establishment" is not "self-defining," 186 and that Establishment Clause challenges are thus "heavily dependent on the specific context and content of the display." 187

He then proceeded to turn to the "traditional standard"- the Lemon test; ${ }^{188}$ combining it with the endorsement test, ${ }^{189}$ he found no violation in the actions of the school district. ${ }^{190} \mathrm{He}$ found the crosses on the maintenance vehicles, and those in the mural, reflected the city's name rather than any improper religious purpose. ${ }^{191}$ Unspoken in the opinion is the underlying question: if a city may not have religious imagery in its

183. Id. at 1075 (citing Separation of Church and State Comm. v. City of Eugene, 93 F.3d 617, 618-20 (9th Cir. 1996)). In some ways the Sunrise Rock case was easier for the Ninth Circuit than the cross in Eugene had been: the cross in the Mojave sat amid a "vast" preserve, ninety percent of which the federal government owned, Buono, 502 F.3d at 1086 (citing Buono v. Norton, 371 F.3d 543, 550 (9th Cir. 2004)), and the government retained rights of management and control of the land even after the transfer. Id. at 1083.

184. Buono, 502 F.3d at 1082 n. 13 .

185. Weinbaum v. Las Cruces Pub. Sch., 465 F. Supp. 2d 1182, 1185 (D.N.M. 2006), aff'd, 541 F.3d 1017 (10th Cir. 2008).

186. Id. at 1191 (quoting McCreary County v. ACLU of Ky., 545 U.S. 844, 874-75 (2005)).

187. Id. (quoting O'Connor v. Washburn, 416 F.3d 1216, 1222 (10th Cir. 2005)).

188. Id. The Court noted that the Van Orden plurality had not used Lemon, but the case had also not overruled it. Id. at 1192 .

189. Id. at 1191 (citing Lynch v. Donnelly, 465 U.S. 668, 687-94 (1984) and County of Allegheny v. ACLU Greater Pittsburgh Chapter, 492 U.S. 573, 595 (1989)).

190. Id. at 1193.

191. Id. at 1194. 
official seal if its name is not based on religion, ${ }^{192}$ why may a city have a religious name? ${ }^{193}$

\section{The Bible Monument ${ }^{194}$}

The federal court did not seem terribly interested in the story of William Mosher. A citizen of Houston, he was clearly a hero to some; upon his death, the Star of Hope Mission, a religious charity that benefited the poor, set up a monument in his honor. ${ }^{195}$ The monument, which sat on the grounds of the Harris County Civil Courthouse, was not a statue, but rather a large pedestal with a glass top that originally contained a Bible. ${ }^{196}$ The passage it originally displayed, if it sat open at all, went unmentioned in the court's opinion. It is clear, however, that the sight of a book under glass proved very tempting to some members of the Houston community. Someone smashed the glass and took the original Bible. ${ }^{197}$ Later replacements, installed at their own expense by Star of Hope Mission, met a similar fate. ${ }^{198}$ Presumably exasperated, the mission gave up and stopped replacing the Bibles in 1988. ${ }^{199}$

Things were quiet for almost a decade until the election campaign of John Devine for district judge, a campaign which overtly sought to introduce Christianity into government. ${ }^{200}$ After his election, he organized a fundraiser to repair the Mosher monument, installing a Bible and a red neon light to illuminate the Bible during hours of darkness. ${ }^{201}$

192. See id. The Court discussed a number of recent precedents in which courts enjoined cities from including crosses on their city seals, including Robinson v. City of Edmond, 68 F.3d 1226 (10th Cir. 1995), Webb v. City of Republic, 55 F. Supp. 2d 994 (W.D. Mo. 1999), and ACLU of Ohio v. City of Stow, 29 F. Supp. 2d 845 (N.D. Ohio 1998). Weinbaum, 465 F. Supp. 2d at 1194. Interestingly, the Court includes in its list the case of Harris v. City of Zion, 927 F.2d 1401 (7th Cir. 1991), but it makes no effort to explain how that city in Illinois, founded by a minister as an overtly religious place and governed by "the Theocratic Party... for more than two generations," id. at 1424 (Easterbrook, J., dissenting), differed constitutionally from Las Cruces. Weinbaum, 465 F. Supp. $2 \mathrm{~d}$ at 1194.

193. Indeed, I confess that I have always been struck by the unstated irony of Lee v. Weisman, 505 U.S. 577 (1992). The Court struck down the eighth-grade graduation prayer with only one, utterly non-ironic, mention of the fact that the case arose in a city named Providence. See id. at 580.

194. Staley v. Harris County, 461 F.3d 504, 507 n.3 (5th Cir. 2006) (noting that news reports referred to it as the Bible monument, rather than as the Mosher monument).

195. Id. at 506 .

196. Id.

197. Id.

198. Id.

199. Or, perhaps, removed the Bible. There is some evidence that about this time there were serious complaints from atheists about the monument. $I d$.

200. Id. at 507 .

201. Id. 
A number of Christian ministers attended the reinstallation ceremony and led prayers; they also sang "The Battle Hymn of the Republic." 202

An atheist lawyer whose practice necessitated frequent trips to the courthouse challenged the monument in federal court. ${ }^{203}$ The district court found a violation of the Establishment Clause, and the Fifth Circuit agreed. $^{204}$ The appellate court's approach to this admittedly extraordinary set of facts illustrates the current difficulties with doctrine in this area. The majority relied almost exclusively on the two 2005 cases, although they used McCreary County to import the purpose prong of the still-vibrant Lemon test. ${ }^{205}$ More significantly, the court drew from that case the relevance of history, noting that "the entire history" is relevant to the judicial inquiry. ${ }^{206}$ When turning to Van Orden, the court went directly to Justice Breyer's concurrence, noting that it was the controlling opinion for precedential purposes. ${ }^{207}$ The court referred repeatedly to Justice Breyer's focus on history and context. ${ }^{208}$

Applying these history-oriented guidelines to the Mosher monument, the court noted that the original monument might well have survived a contemporary challenge. ${ }^{209}$ Nevertheless, subsequent events, including the refurbishment and rededication in 1995, meant that the monument had "evolved into a predominantly religious symbol." 110 Thus, for the court, the purpose inquiry itself could take into account change over time, a position that provoked a fierce dissent. ${ }^{211}$

The court's approach may not demonstrate the "appalling hostility to any hint of religion in public spaces" of which the dissent accused it, ${ }^{212}$ but it does lead to some rather odd results. As the dissent noted, at some time in the future, the Star of Hope Mission could reinstall the Bible in the monument, in an appropriately secular ceremony, and this would satisfy the Establishment Clause. ${ }^{213}$ Indeed, as a matter of logic, the

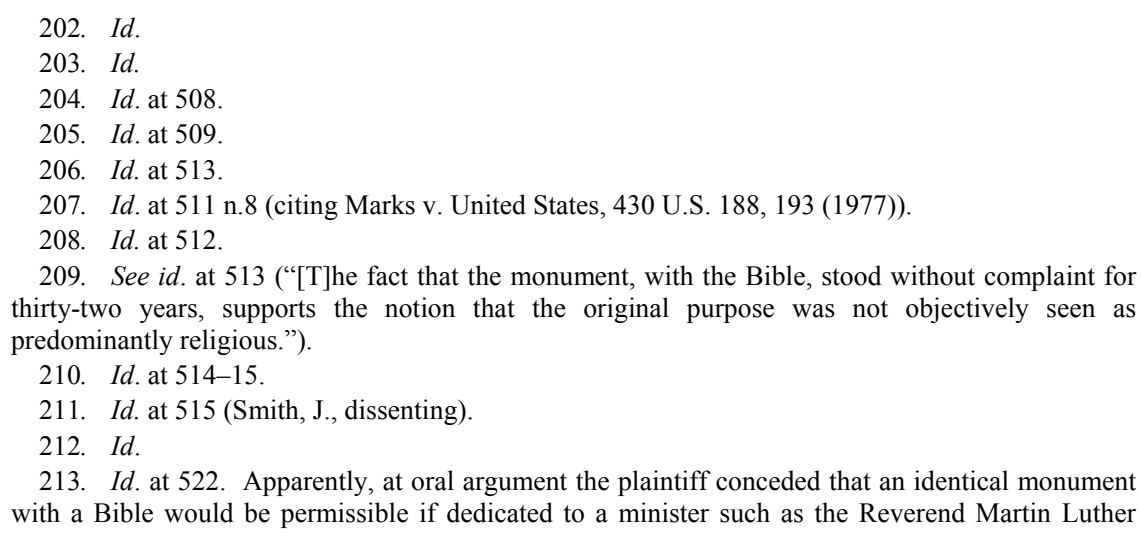

213. Id. at 522. Apparently, at oral argument the plaintiff conceded that an identical monument with a Bible would be permissible if dedicated to a minister such as the Reverend Martin Luther 
Fifth Circuit approach might well forbid a secular monument if government officials began incorporating it into worship or other religious activities.

The Copenhagen approach, on the other hand, would avoid the problem of transferred intent altogether. It would not matter whether the court could find a primarily secular purpose at installation, or even repair. Instead, the court would focus on the effect on the community of the removal of the Bible and its red neon light. Although a close case, the kind that probably would require significant fact-finding by the trial court, it is possible that such an approach would have allowed the Bible to stay, but required the lighting to go. ${ }^{214}$

\section{The Divine Comedy}

From the perspective of the Copenhagen test, there has been no more unfortunate recent case than that which arose in the "somewhat bucolic" ${ }^{215}$ setting of Stigler, Oklahoma. In that small town in 2004, a local citizen and part-time minister received divine guidance that Stigler needed a Ten Commandments monument on its courthouse lawn. ${ }^{216} \mathrm{He}$ raised the money for it himself, obtained the monument, ${ }^{217}$ and led the dedication ceremony that the court called "mostly religious in nature." 218 In less than a year, opponents filed a lawsuit, arguing rather conventionally that the monument lacked a secular purpose and endorsed a particular religious group. ${ }^{219}$ During the course of the lawsuit, a rally took place that was designed to support the monument. ${ }^{220}$ In attendance were two of the County Commissioners, one United States Senator, and several local preachers, whose speeches, in the court's words, "were both

King, Jr. $I d$.

214. Truth is always stranger than fiction; and in the fact-heavy world of current Establishment Clause law, the story of the Mosher monument became even stranger outside of the federal courts. Before the Fifth Circuit could hear the case en banc, the county made it moot by removing the entire monument to storage due to an ongoing stairway renovation project at the courthouse. Staley v. Harris County, 485 F.3d 305, 307 (5th Cir. 2007). The Circuit dismissed the appeal, see id. at 309 (citing that the appeal was moot), but did not vacate the District Court's injunction requiring removal of the Bible. Id. at 314. The monument remains in storage to date, although the county attorney has said they may install it elsewhere on county property. John MacCormack, Bible Saga Won't See High Court Docket, SAN ANTONIO EXPRESS NeWS, Nov. 27, 2007, at B1.

215. Green v. Bd. of County Comm'rs, 450 F. Supp. 2d 1273, 1274 (E.D. Okla. 2006).

216. While eating lunch, "he felt as if "the Lord laid a burden on [his] heart." Id. at 1276.

217. The monument contains an abbreviated version of the Ten Commandments on one side, including the misspelled word "adultry"; on the other it contains a portion of the Mayflower Compact. Id. at 1276-78.

218. Id. at 1276.

219. Id. at 1279.

220. Id. at 1280 . 
political and religious in nature."221 A Copenhagen approach would likely find this to be an easily resolved case. Although those who installed it and rallied on its behalf would no doubt take removal of the monument poorly, a decision to allow it to remain would only serve notice that contemporary placement of such overtly religious monuments before courthouses was perfectly legitimate. The creation of more such monuments, with the inevitably accompanying social discord, would ensue. $^{222}$

Unfortunately, the District Court hearing the case did not adopt a Copenhagen approach and take account of the impact of its own opinion on religious strife. Indeed, it is difficult to isolate the analytical model that the court used to resolve the case. The judge dismissed the 2005 cases as unhelpful, ${ }^{223}$ focused on the outdoor location and private funding as the circumstances most relevant to making the case at issue like Van Orden rather than McCreary County, ${ }^{224}$ and castigated Justice Breyer for his focus on the role of history. ${ }^{225} \mathrm{He}$ even hinted that those opposing the monument showed religious intolerance. ${ }^{226}$ By ignoring the contemporary events, the court ignored the obvious concerns of both the McCreary County majority and Justice Breyer's Van Orden concurrence. $\mathrm{He}$ referred on several occasions to the small, intimate nature of the town, ${ }^{227}$ but audaciously claimed that when a County Commissioner "spoke a few defiant words" 228 at the rally, ${ }^{229}$ a reasonable observer would not conclude that "he attended in his official capacity.",30 The

221. Id.

222. Indeed, it is not clear which begat which, but there seems to be a second recently installed monument that contains the same jarring spelling error "adultry." See Sherri Day, Monument Fight Lacks a Fighter, ST. PETERSBURG TIMES, Jan. 2, 2007, available at http://www.sptimes.com/2007 /01/02/State/Monument_fight_lacks_.shtml; see also The Society for the Promotion of Good Grammar, The Devil's in the Details, Dec. 3, 2006, http://grammatically.blogspot.com/2006_12 _01_archive.html (close-up of monument).

223. In referring to McCreary County and Van Orden, the opinion notes that "[o]ne might think that two such recent precedents addressing the same subject would drastically simplify a trial court's quest in deciding whether the Monument at issue here withstands constitutional scrutiny. One might be wrong." Green, 450 F. Supp. 2d at 1284.

224. Id. at 1291.

225. The important factor for the court is "the objective effects of an edifice," which would exist long after any accompanying governmental pronouncements "are past and forgotten." Id. at 1289.

226. "Also, exactly why would a newer display be more divisive than an older one? Is it, as Justice Breyer suggests, because of our supposedly increased religious diversity? Or, is it because our nation is actually less religiously tolerant than earlier in our history?" Id. at 1288.

227. See id. at 1276, 1280 ("[E]veryone knows each other.").

228. Id. at 1290 .

229. He threatened to stand in front of the monument and make any bulldozer roll over him before it could reach the Ten Commandments Monument. Id. at 1280 .

230. Id. at 1290 . 
opinion is filled with facts that depict a McCreary County-like infusion of religion into politics. The court ignored the implications of them all.

What makes the case tragic is that it is brilliantly written. Judge White's alliteration, plays on words, and tongue-in-cheek style have been justly recognized for their excellence. ${ }^{231}$ It is the very quality of the writing, though - to say nothing of its structural references to Dante's Divine Comedy - that makes so jarring the judge's overt hostility to the effort to remove this very recent, very religious, and very divisive monument. ${ }^{232}$

\section{The Neglected Value: Religious Peace}

Ultimately, an offer of a new paradigm for Establishment Clause cases must bring some advantage over the current chaos. As the cases just discussed demonstrate, a Copenhagen view does not create a bright line or black letter rule that will prove easy to apply in a mechanical way. A court taking account of its own role, though, might bring to the decision-making process an undervalued concern in current jurisprudence: the maintenance of what we might call "religious peace." ${ }^{233}$ The Framers of the Constitution were well aware of the danger that strongly held religious views posed for the unity of the

231. The opinion was one of six chosen for inclusion in Exemplary Legal Writers 2006, 10 GREEN BAG 152 (2007).

232. Green, 450 F. Supp. 2d at 1281-82 (noting that one of the Commissioners disliked one of the plaintiffs because he was "a courthouse gadfly," criticizing a member of the other for her "selfrighteous indignation," while finding that the Commissioners' "down-to-earth demeanor betrayed no dissembling, artifice or deception"). The court later announced that it would not allow the plaintiffs to file a federal claim, "bask smugly in the resulting frenzy," and then use the frenzy to show an Establishment Clause violation. Id. at 1290-91.

233. The phrase may have arisen from the 1555 Act of the Diet of Augsburg of the Holy Roman Empire that endeavored to create a "permanent and perpetual peace... in regard to religious disputes." Herman Tüchle, The Peace of Augsburg: New Order or Lull in the Fighting, in GOVERNMENT IN REFORMATION EUROPE, 1520-1560, at 145 (Henry J. Cohn ed., 1971). In an early example of increasing religious pluralism over time, only Roman Catholicism and Lutheranism were permitted within the Holy Roman Empire from that date until 1648, when the Peace of Westphalia following the Thirty Years' War added Calvinism as a third legal religion. See 2 AnTON GindELY, HistORY OF THE THIRTY YEARs' WAR 372 (Andrew Ten Brook trans., Books for Libraries Press 1972) (1885). 
fragile new nation. ${ }^{234}$ Indeed, the history they relied on included powerful examples of religions shattering nations. ${ }^{235}$

Current doctrinal confusion does little or nothing to further religious peace. Indeed, some of the Justices whom one might expect to support such a goal have spoken against it directly. ${ }^{236}$ It might be thought to smack a bit too much of instrumentalism, which may rival "activism" for pride of place in the list of judicial deadly sins. Justice Breyer's concurring opinion in Van Orden provoked precisely the charge that he was concerned with the effects of the Court's decision, a concern that struck at least some of his colleagues as fundamentally wrong. ${ }^{237}$ The judiciary, say critics of decision-making that considers outcomes, should be above such petty concerns. The proper judge should be a neutral participant, an umpire, seeking a neutral solution in these Establishment Clause cases.

If, though, the observation of Chuang Tzu is correct, there can be no neutrality when deciding government religious activity; the display may stay, or it must go. In any event, it is difficult to see what could be worse with a Copenhagen approach. The experience of the later FALG cases shows that a purpose inquiry leads to a tactical deployment of the Lemon test to insert divisive new religious materials into government activity. Indeed, opinions like that of District Judge White ${ }^{238}$ would seem, by ignoring or belittling the religious strife in the community, to aggravate rather than ameliorate the difficulties.

234. In his list of the "latent causes of faction," Madison began with "a zeal for different opinions concerning religion," although he did note that "the most common and durable source" was the "unequal distribution of property." THE FedERAlist No. 10, at 131 (James Madison) (Benjamin Fletcher Wright, ed. 1961). That Madison was concerned about religion at all speaks volumes when taken in the context of the earlier essay by John Jay which maintained: "Providence has been pleased to give this one connected country to one united people ... professing the same religion." Id. No. 2, at 38 (John Jay).

235. See, e.g., the discussion of Switzerland in THE FEDERALIST No. 19 (James Madison), id. at 180-81 (arguing that the cantons of Switzerland did not really constitute a confederacy, and that the Protestant-Catholic divide had essentially ended their common enterprise). This recognition of Swiss division was prescient; sixty years later the Swiss Confederation would divide along the lines noted by Madison and fight a brief civil war. See ChARLES Gilliard, A History OF SwitzerLand 88-91 (D.L.B. Hartly trans., 1955); E. BONJOUR ET AL., A SHORT HISTORY OF SWITZERLAND 26165 (1952).

236. In explaining the endorsement test, Justice O'Connor rejected the crèche's opponent's reliance upon political divisiveness, refusing to elevate it to "an independent test of constitutionality." Lynch v. Donnelly, 465 U.S. 668, 689 (1984).

237. Van Orden v. Perry, 545 U.S. 677, 692 (2005) (Scalia, J., concurring).

238. See supra Part IV.B.6 (analyzing the opinion of Green v. Bd. of County Comm'rs, 450 F. Supp. 2d 1273 (E.D. Okla. 2006)). 


\section{CONCLUSION}

Ultimately, then, this is a plea for a prudentialism that accounts for both the current state of the region and the historical background of the government speech at issue. These two views, called (albeit in a decidedly different context) the historical and temporal dimensions by Professors Levinson and Balkin, ${ }^{239}$ allow the court to recognize the broader context of the society in which it is intervening before it acts. To put this idea back into the terms of physics, the court recognizes that it inevitably will affect the path and spin of the electron, so it should at least be aware of as much of its surroundings as possible before doing so.

Use of a Copenhagen model, an admittedly self-referential model of Establishment Clause jurisprudence, would certainly not solve all problems easily. Nor would it immediately end the current political hostility over the role of religion in society. It would offer, however, a cease-fire. Members of faiths which are majorities in particular areas would be unable to use the government to trumpet their own beliefs, as they would almost certainly face an immediate response from those who dissent. Even where that was not so, courts might legitimately prevent new government religious speech on the ground that it would encourage other, more divisive acts. On the other hand, those who seek to remove the vestiges of pre-existing religious speech throughout the nation's towns and cities would quickly discover that courts would have very little willingness to order the removal of old monuments unless the society had turned against them so completely that a court case would not be necessary.

Ultimate political solutions to seemingly intractable problems can seldom be offered by the judiciary. Perhaps it is a pipe dream to hope that during such a period of enforced peace, true tolerance could be discovered between the forces of nonreligion and those of religion. Perhaps it is too much to hope that such an approach by the courts would create a "permanent and perpetual peace" ${ }^{40}$ among warring faiths. Having the judiciary recognize its role and endeavor to withdraw from the battle, though, might help such a truce to become, over time, habitual.

239. Sanford Levinson \& Jack M. Balkin, What are the Facts of Marbury v. Madison? 20 CONST. COMMENT. 255, 273 (2003).

240. See Tüchle, supra note 233, at 145. 